\title{
A COMMENT ON THE ARTICLE "LOYALTY AMONG GOVERNMENT EMPLOYEES":;
}

\section{J. EDGAR HOOVER†}

I HAVE read the article, "Loyalty Among Government Employees," which appeared in the December, 1948, issue of The Yale Law Journal. Since inaccuracies, distortions and misstatements appear with reference to the FBI in the article, I would appreciate, in all fairness, the same extent and scope of publication with respect to the correction of such inaccuracies as were given the original article.

The FBI did not initiate or establish the Federal Employee Loyalty Program. The program is based on an Executive Order issued by the President of the United States. Congress appropriated the funds to carry out the order. The function of the FBI in the program is twofold: 1 . To check the fingerprints and names of Federal employees and applicants against its files, and 2. To obtain and report facts ascertained during investigation of persons alleged to be disloyal.

The FBI does not orally, in writing, or otherwise make any recommendations or draw any conclusions as to action to be taken with respect to Federal employees under this program. The views of the authors as to the wisdom of the program, although not consistent with the view at that time of the President or the Congress, are not pertinent to the subject of this communication.

Since many of the references to the FBI are so obviously incomplete and distorted, I have the following specific observations and comments to make:

Page 45:

In discussing criteria of disloyalty, the following observation is made in the footnote, after correctly quoting me on the fact that the FBI is a fact-finding agency, "The truth is, of course, that in deciding what facts to report the FBI makes constant judgments of relevancy."

\section{Comment:}

The facts are that FBI Special Agents are under instructions to report all information conveyed to them. For example, the authors refer to a case on page 72 . If the authors and I are referring to the same case, our reports showed a comment by the investigating Agent that the person interviewed claimed the Government employee in question had been or was a member of the Communist Party. The

* Communication to the Yale LAw Jounsal, dated February 7, 1949, concerning the article by Messrs. Emerson and Helfeld, 58 YaLE L. J. 1 (194S).

$\uparrow$ Director, Federal Bureau of Investigation. 
Agent then reported that the witness had been drinking for some time but he was not drunk. This observation might very well aid reviewing officials in determining the credibility of the witness' statement.

This same file contains the information that, "Twenty of these persons regard him (the Government employee) as a liberal, but not Communistically inclined and a loyal American. Four of them assert that he has consistently followed the Communist Party "line."

Page 68:

"The authority of the FBI to undertake an investigation is, for all practical purposes, unlimited."

\section{Comment:}

This statement is inaccurate. Although the authors later on in the same paragraph correctly state that the FBI investigates "on its own motion in any case where it receives information or a complaint which, if established, would come within the Directive set forth in the President's Executive Order." This is typical of the manner in which the program is presented in the article and why I would have more respect for the integrity of the authors had they levelled a frontal attack on the program. The FBI investigates only when there is a reason, which must be based upon fact.

On page 68 , the authors' statement that adequate information concerning the investigative methods of the FBI is not obtainable conveys an erroneous impression. We have nothing whatsoever to conceal about our investigative methods to authorized officials, nor do we have any secrets as to the substance of the investigation of Loyalty cases except the identity of confidential sources of information.

Page 68:

The authors contend that, " . . . certain facts are available which illustrate the dangers inevitable in loyalty investigations."

\section{Comment:}

The first instance cited by the authors to substantiate their contention is a letter directed by the FBI to the chairman of the National Labor Relations Board. In a footnote, they admit that the letter was dated November 14, 1940, almost seven years before the Loyalty Program was inaugurated, but they do not say that the letter quoted merely transmitted information furnished the FBI by another highly respected Government agency. The FBI merely relayed the information to the National Labor Relations Board. Later, the FBI was requested to investigate the person mentioned in the letter and on the 
basis of our investigation the National Labor Relations Board exonerated him of charges of possible disloyalty. By furnishing only partial facts the authors convey an erroneous impression.

Page 69:

Former FCC Commissioner Clifford J. Durr is quoted at length in justification of a criticism he had levelled at the FBI.

\section{Comment:}

The statement quoted occurred at a meeting of the Federal Communications Commission following Commissioner Durr's denunciation of the FBI in a speech wherein he severely criticized the Bureau for sending unsolicited information to the FCC. It so happens that the FBI has long followed a policy, approved by several Attorneys General, of relaying information believed to be of interest to other Government agencies. This has been done for years. In fact, some of the information Commissioner Durr complained about had been specificially requested by the then Chairman of the Federal Communications Commission.

The FBI, after Durr's speech complaining that the FBI was forwarding data on subversives to FCC, formally advised the Commission that if Mr. Durr was reflecting the views of the Commission, the FBI would henceforth refrain from forwarding such information to the FCC. As a footnote hints, the FCC repudiated the Durr charges and requested the FBI to continue to forward information. In fairness, it is noted that the authors did in small type observe that Commissioner Jones charged that Durr's material was "completely out of context." Nevertheless, to the uninformed reader an entirely different impression pertaining to the FBI is conveyed and one which is not supported by the facts.

Pages 69 and 70:

The authors cite cases alleged to be an indication of types of reports in Loyalty investigations.

\section{Comment:}

While all of the cases cited cannot be identified, I am certain that the facts will reveal that only excerpts have been selected from reports to fit the convenience of the authors. Certainly, it would appear that statements picked at random and probably out of context are no criteria of the completeness of an investigation. Such tactics are alin to withholding facts from a court because they were unfavorable to a litigant. 
Page 70:

Lists a series of questions allegedly asked by Special Agents of the FBI in Loyalty cases.

\section{Comment:}

Most of the questions enumerated are not asked by the FBI and certainly not the ones pertaining to personal habits and the nature of literature read. I have heard the question, "Do you read the New Republic?" alleged before. In fact, officials of that publication have made the charge. Whenever they have been willing to furnish identifying data which made investigation possible, it has been conclusively proven that it was not FBI Agents who asked the questions.

\section{Page 71:}

"FBI methods include the use of paid informers."

\section{Comment:}

This is correct. How else is it possible to secure certain types of information? The most important espionage case in American history was solved through the services of a paid informant of the FBI. By the same token, how could the FBI in certain Loyalty investigations report that the Federal employee had issued to him a membership card of the Communist Political Association No. 35985, Communist membership card No. 83987, Communist Party dues book No. 79298, Communist Registration Card No. 67202, Communist Care No. 79418, without utilizing paid informants?

\section{Page 71:}

"Persons making statements are not under oath and are assured that their identity will not be revealed."

\section{Comment:}

The FBI does not have authority under the Federal Employee Loyalty Program to administer oaths. Persons called to testify before Loyalty Hearing Boards are put under oath. In the investigations the FBI makes every effort to secure signed statements from persons furnishing derogatory information and except in those instances of persons who have succeeded in penetrating the ranks of subversive organizations, they are assured that their identities will not be revealed only after they state that this is the only condition upon which they will furnish information; and then this is done with the approval of the Loyalty Review Board and the Attorney General. In fact, the Presi- 
dent's Executive Order provides for the non-disclosure of the names of confidential informants. Experience thoroughly justifies a continuance of such procedures.

\section{Page 71:}

"The reports transmitted to the employing agency usually refer to the source of information by symbols only."

\section{Comment:}

Symbols are used to designate confidential sources of information. However, under the Federal Employee Loyalty Program, signed statements frequently are transmitted to Loyalty Hearing Boards. It is noted that the authors in their footnotes continually refer to sources of information in cases which occurred years ago. To keep the record straight, the Federal Employee Loyalty Program did not get under way until the fall of 1947.

Page 71:

"Although the FBI denies that it taps telephones, instances of that practice have been reported and it is widely believed in Washington that many telephones are in fact tapped."

\section{Comment:}

I challenge the authors to come forward with one single instance wherein a telephone was tapped in the investigation of a Federal Employee Loyalty Program case. It is no secret that the FBI does tap telephones in a very limited type of cases with the express approval in each instance of the Attorney General of the United States, but only in cases involving espionage, sabotage, grave risks to internal security, or when human lives are in jeopardy. This is never done in the investigation of the loyalty of Federal employees. This unsubstantiated statement by the authors typifies their obvious efforts to discredit the work of the FBI in Loyalty cases.

\section{Page 71:}

"The FBI maintains files on numerous individuals." But the footnote conveys the erroneous impression that the FBI has files on all subversives.

\section{Comment:}

My statement, cited in the footnote, appeared in an article in the New York Herald Tribune on November 16, 1947, and read as follows: 
"We keep files only on those people and organizations we investigate as a result of information or a complaint coming within our jurisdiction. What a citizen says, thinks or does is his business, not ours, so long as he is not alleged to violate Federal laws. Contrary to popular belief, the FBI does not keep files on all people in the United States. We keep files pursuant only to the diszharge of the responsibilities imposed upon the FBI by law."

In testifying before the House Committee on Appropriations on December 10, 1947, the following is quoted from page 248:

\begin{abstract}
"Mr. Rooney. For instance, in the city of New York where the police department had a subversive squad during the war, they have a substantial file and gave you the advantage of all the information they had. So that when you are checking these names given by the Civil Service Commission, you are checking them against quite a comprehensive file which we might say would in= clude everybody who had been involved in any activities of a subversive nature.

"Mr. Hoover. Or that would be potentially dangerous."
\end{abstract}

By no stretch of the imagination did I say that the FBI files, "include everybody who had been involved in any activities of a subversive nature," as indicated in The Yale Law Journal article. Congress* man Rooney referred to "A substantial file . . . quite a comprehensive file" in the New York City Police Department. To keep the record straight, let me reiterate that we have files only on those we investigate or on those investigated by other agencies and concerning whom reports have been forwarded to the Bureau.

Page 72:

"The average FBI Agent can hardly be expected to possess the political education necessary to distinguish between radicalism and subversion; he must be instructed to secure all scraps of information available."

\title{
Comment:
}

The authors indict their own profession with this statement because FBI Agents with very few exceptions are the products of our colleges and universities, including Yale Law School. Political education is not necessary as we do not investigate political activities, unless the authors hold to the view that organizations such as the GermanAmerican Bund and the Communist Party are political activities. These groups would like to have the public believe that such is the case rather than have themselves viewed in their true light of "Fifth Columnists." The FBI does not, has not, and never will so long as I am Director investigate political views. 


\section{Page 72:}

"The collection of gossip, rumor and data on private affairs becomes an inevitable part of the process."

\section{Comment:}

This statement is untrue. In each instance, Agents inquire of persons interviewed, when they express conclusions, for the facts upon which they base their conclusions. If a matter is reported as rumor or gossip the Agents try to ascertain the source of the statements so that their truth or falsity can be established. Of course, the authors should know that the first defense in such cases is a denial and if that fails then an attempt is made to label the information as rumor or gossip. The authors likewise should know the dificulties often present in proving disloyalty, particularly on the part of one who masquerades behind the cloak of respectability; and the investigations are not secret, as they are characterized by the authors. FBI reports are sent to the Civil Service Commission and to the employing agency. If they contain statements of witnesses challenging the employee's loyalty, appropriate charges are drafted in the employing agency and not by the FBI. In fact, the authors prove this point in their article with a recital of questions asked by Loyalty Hearing Boards.

\section{Page 72:}

"Efficiency ratings tend to turn upon how much 'derogatory information' a particular investigator uncovers. This sort of bias is even more likely to flourish where the results of investigation are not subject to judicial scrutiny. Nor can one normally expect to spend \$11,000,000 in the Federal Government without results to show for it, particularly when members of Congress are clamoring for action."

\section{Comment:}

This statement is a libel upon the integrity of every member of the FBI as well as of Congress. The charge that efficiency ratings of FBI personnel are predicated in any manner upon how much "derogatory information" an employee develops against anyone is a complete falsehood. The FBI record speaks for itself. Instructions that have been in effect since I assumed the Directorship of the Bureau have been that our Agents are to obtain the facts. We are interested in justice-securing facts as to innocence as well as guilt.

I have no apologies for spending the money appropriated by Congress for the operations of the FBI, which over the years have netted the taxpayers in fines imposed, savings to the Government and recoveries of stolen property far more than its total cost of operations. This does not take into account the record of the FBI over the years 
in many fields of activity, such as meeting the kidnapping menace and completely avoiding sabotage during World War II.

Page 76:

"He [the Federal employee] is acutely aware that an FBI investigation can be initiated upon the basis of a complaint made by an unfriendly or psychopathic acquaintance."

\section{Comment:}

If the pages of the Law Journal of one of our great law schools can be used to distort and misrepresent truth I cannot take the above charge seriously; but the article fails to point out that the Government employee as the result of the Loyalty Program is protected from unfriendly or psychopathic acquaintances. If complaints are based upon falsehoods the resulting FBI investigation will prove them to be the liars that they are. The authors, unfortunately, do not speculate on how gossiping and the spreading of rumors can be stopped. I wish they could supply the answer to this age-old trait of human beings. In fact, their article contains rumors or figments of the imagination concerning the manner in which the FBI operates which have no basis whatsoever.

Page 77:

"Under the Loyalty Order any applicant whose name is listed unfavorably in the files of the Committee on Un-American Activities is at once a suspect and subject to an intensive FBI investigation."

\section{Comment:}

Obviously we would investigate allegations that come within the frame work of the President's Executive Order to establish their truth or falsity regardless of the source. We do not investigate non-specific complaints or in instances where we have already established the facts pertaining to the complaint.

Page 77:

"It is unlikely that there will be an extensive use of the formal procedures in the case of prospective employees. In effect this places a veto power on Government employment in the hands of the FBI."

\section{Comment:}

This statement alone in my opinion tests the credibility of the entire article. The FBI never acts as prosecutor or judge. Suppose, for example, the prospective Government employee is a convicted perjurer, bank robber or white-collared member of the Communist under- 
ground. The FBI reports the facts it obtains and forwards the report without recommendation as in all Loyalty cases, to the Civil Service Commission. Should the Government agency elect to hire him after that, it may do so. If it elects to reject the applicant, surely criticism is not to be directed at the FBI for uncovering the acts and the facts as to the applicant.

If the authors have evidence of improper actions on the part of the FBI and will furnish me a bill of particulars, I will promise that their informants will not be embarrassed and that I will have a vigorous, impartial, administrative investigation made. If disciplinary action in the FBI is warranted, it will be taken. If, on the other hand, we have been wronged by unfounded charges all I ask is that the record be kept straight. I make this offer in good faith and expect in return to be treated in good faith.

Pages 101-109:

Much is made about the FBI's refusal to identify confidential sources of information.

\section{Comment:}

Shortly after the President's Loyalty Order was issued, I appeared before the Loyalty Review Board and frankly discussed the problems of sources of information. In fact, my testimony before the House Committee on Appropriations is cited as a footnote on page 108 and brushed off with the statement, "For the FBI defense of the practice see testimony of J. Edgar Hoover before House Appropriations Committee. ..." where I outlined in detail my appearance before the Loyalty Review Board.

I outlined the alternatives to the Loyalty Review Board and asked what that Board wanted us to do. I offered to submit reports with no confidential sources appearing therein and I offered to adopt the policy of not accepting any information if the source had to be concealed. The Board refused this offer because they put the interests of the Government and the security of the nation above the whims and convenience of the individual. In fact, the Board did no more than to follow the wise words of that great liberal, the late Associate Justice Oliver Wendell Holmes, who ruled in McAuliffe vs. New Bedford (155 Mass. 216) that, "The petitioner may have a Constitutional right to talk politics, but he has no Constitutional right to be a policeman. There are few employments for hire in which the servant does not agree to suspend his Constitutional right of free speech, as well as of idleness, by the implied terms of his contract."

As to the sources of information, if the responsibility were given the authors I dare say that the confidential informants who provided us 
with Communist cards No. 36485 , No. 46854 , No. 46734 , No. 76577 , and the numerous others we have secured and forwarded to the appropriate authorities would never be disclosed. Unlike a criminal case, these informants are sources of information in many cases. So far as Loyalty proceedings are concerned, they do not have the protection of subpoena nor can they be required to testify. Then, too, there is the individual who will furnish information only on condition that his identity be protected. Is the Government to be deprived of this information? I dare say the majority of the citizens of this nation if given the right to vote would say, "No!"

The authors kindly referred to the record of the FBI in preventing sabotage and espionage during the war. This was made possible in a large measure because of sources of information both in this country and abroad, whose identity must be protected so long as they or their immediate families survive.

\section{Page 141:}

"The FBI and other professional investigating agencies should be subjected to a greater degree of 'civilian' control. The FBI, in particular, operates on a completely independent basis, acknowledging little or no responsibility to anyone outside its own organization. Inevitably such an institution develops an ingrown tradition of militant police methods. A secret police established to investigate the 'loyalty' of American citizens can develop into a grave and ruthless menace to democratic process. There are signs that the FBI is moving dangerously in this direction."

\section{Comment:}

Any doubts that I have had about the authors' sincerity or competence to write on this subject from the standpoint of knowledge of the various ramifications of the Loyalty Program were completely resolved by the above statement. I realize, of course, that largely it is the opinion of the authors, which they have every right to express; however, I find such opinions most frequently expressed on the pages of The Daily Worker, the publication of the Communist Party, and at least I would expect a higher plane of objectivity in the pages of The Yale Law Journal.

The FBI has been and is now under civilian control. It will continue to be, so long as I have any connection with it.

In 1924, when the Department of Justice was reorganized by the then Attorney General, Harlan Fiske Stone, the late Chief Justice of the United States, who first designated me as Director, there were several lengthy conversations between us as to the future role of the FBI. From these conversations evolved the operating policies that were placed into effect then and remain in effect today. Over the years 
the late Chief Justice kept a close watch over the Bureau and I now feel it appropriate to reveal that it was my privilege to turn to him for counsel, advice and guidance, which he freely gave both when solicited and unsolicited when he felt it was appropriate. I always looked to the late Chief Justice as a friend and adviser. His impact upon the FBI and upon me has been felt over the years and has had a real place in the development of the FBI.

The policy was laid down as a result of Mr. Stone's views and from which there has been no deviation over the years, that the role of the FBI was to obtain facts. The FBI is solely responsible to the Attorney General. I have known rather intimately each Attorney General since then and to label any of them as other than exponents of the "civilian viewpoint" would be to utter a falsehood. Beyond that, the FBI must justify its every activity to the President, the Appropriations Committees of both houses of Congress, and finally to Congress. Furthermore, this nation still has a free press, which is one of the greatest protectors of our democratic institutions. Should the FBI at any time exceed the realm of propriety and violate civil rights, the judiciary still functions and I have never entertained the slightest doubt that if the FBI's actions became improper the courts would be appealed to with dispatch.

The FBI as it is now constituted could never be a "ruthless menace" to democratic processes because of the character and the training of the men who constitute its investigative force. Even if the Director of the FBI desired to adopt totalitarian methods of operation, he could not expect the present staff of the FBI to carry them out.

I frankly do not know what additional machinery the Attorney General could set up to maintain a closer supervision of the FBI. The various divisions of the Department have the supervision now of cases investigated by the FBI in which they are interested. The various United States Attorneys receive copies of our reports in criminal cases and almost daily in Loyalty cases I refer some problem to the Attorney General for his advice and guidance.

The authors say that, "Only in this way can the abuses inherent in such an institution be effectively kept in check." I wish the authors had enumerated the abuses. Even now, I would like to request a bill of particulars, based upon fact and not the results of whims or personal prejudices, of abuses on the part of the FBI. Should they exist, I am even more anxious than they to correct them because in the final analysis I am responsible for the administration of the FBI.

I regret the necessity of writing at such length. There are many other observations which I would like to make on the distortions that appear in the article; however I feel constrained to comment only upon certain specific references to the FBI. 